\title{
Performance Evaluation of a Compression Ignition Engine using Sand Apple (Parinari polyandra B.) Ethyl ester (Biodiesel)
}

\author{
A. Saleh ${ }^{\mathrm{a}, *}$, F. B. Akande ${ }^{\mathrm{b}}$, D. T. Adeyemi ${ }^{\mathrm{c}}$, O. O. Oniya ${ }^{\mathrm{b}}$ \\ ${ }^{a}$ Department of Agricultural \& Bio-Resources Engineering, Ahmadu Bello University, Zaria, Kaduna State, \\ NIGERIA. \\ ${ }^{b}$ Department of Agricultural Engineering, Ladoke Akintola University of Technology, Ogbomoso, Oyo State, \\ NIGERIA. \\ ${ }^{c}$ National Centre for Agricultural Mechanization, Ilorin, Kwara State, NIGERIA.
}

\begin{abstract}
The quest for non-edible oil for the production of alternative fuel (bio-fuel) using homogeneous catalysts continues to supplement and replace in totality the traditional transportation fuels that are not environmentally friendly. The use of biodiesel in Compression Ignition Engines (CIE) to evaluate the engine performance is a norm and blends of biodiesel and Automotive Gas Oil (AGO) are also used in the engine performance processes to ascertain its usage in the CIE. Therefore, this study evaluated the performance of a compression ignition engine (CIE) fuelled with biodiesel produced from sand apple oil using eggshell as a heterogeneous catalyst. Trans-esterification of Sand Apple Oil (SAO) with ethanol to produce ethyl ester and glycerol was optimized. Sand Apple Ethyl Esters (SAEE) was blended with Automotive Gas Oil (AGO) at $5-25 \%$ mix to evaluate the performance of a $3.68 \mathrm{~kW}$ diesel engine at five loading conditions $(0,25.50,75,100 \%)$. Performance tests were carried out to determine torque, speed, exhaust gas temperature and fuel consumption rate. Data obtained were analyzed using ANOVA at $P<0.05$ significant level. Results of parameters tested ranged from $6.50-6.60 \mathrm{Nm}, 2795-2950 \mathrm{rpm}, 385-400{ }^{\circ} \mathrm{C}$ and $2.93-5.00 \times 10^{-6} \mathrm{~kg} / \mathrm{s}$, respectively for all the blends. The study established that the performance of the diesel engine using 5-25\% SAEE-AGO blends was similar to using AGO alone and SAEE is therefore suitable for use in the CIE.
\end{abstract}

Keywords: biodiesel, sand apple ethyl-ester, transesterification, calcined eggshell, heterogeneous catalyst, performance evaluation criteria

\section{INTRODUCTION}

Biodiesel is a cleaner burning alternative fuel to petroleum-based diesel fuel [1]. Successful introduction of biodiesel in many countries around the world has been accompanied by the development of standards to ensure high product quality and user confidence. Biodiesel is characterized by determining its physical and fuel properties which include density, viscosity, iodine value, acid value, cloud point, pour point, gross heat of combustion and volatility $[2,3]$. The advantages of biodiesel as diesel fuel are its portability, availability, renewability, higher combustion efficiency, lower sulphur, aromatic contents, higher cetane number and higher biodegradability [4]. However, biodiesel has some disadvantages which affect its suitability for use in Internal Combustion

\footnotetext{
* Corresponding author (Tel: +234 (0)803 577 4780)

Email addresses: salehaminu@gmail.com (A. Saleh), fakande@lautech.edu.ng (F. B. Akande), deboajani@gmail.com (D. T. Adeyemi), oooniya@lautech.edu.ng (O. O. Oniya)
}

Engines (ICE), these include its higher viscosity, lower energy content, higher cloud point and pour point, higher nitrogen oxide emission, lower engine speed and power, injector coking, engine compatibility, high price and higher engine wear [5]. Biodiesel offers safety benefits over diesel fuel because it is much less combustible, with a flash point greater than $423 \mathrm{~K}$ compared to 350 $\mathrm{K}$ for petroleum-based diesel fuel [6]. It also has a higher cetane number (48-60) than diesel fuel, no aromatics, no sulphur and contains $10-11 \%$ oxygen by weight $[7,8]$.

The cetane number is a commonly used indicator for the determination of diesel fuel quality, especially the ignition quality. It measures the readiness of the fuel to auto-ignite when injected into the engine. Ease of ignition is one of the qualities of biodiesel that is determined by the structure of the fatty acid methyl ester (FAME) component [4]. Viscosity is the most important property of biodiesel since it affects the operation of the fuel injection equipment, particularly at low temperatures when the increase in viscosity affects the 
fluidity of the fuel [9]. Biodiesel has high viscosity which leads to poorer atomization of the fuel spray by the fuel injectors [10].

Due to the presence of an electronegative element, oxygen, biodiesel has a lower heating when compared slightly with the more polar diesel fuel; as a result, viscosity of biodiesel is higher than diesel fuel. The lower heating value (LHV) is the most important performance index used for engine applications. It is used as an indicator of the energy content of the fuel [11].

The use of homogeneous catalyst increases the cost of production of biodiesel and is difficult to separate from biodiesel than that of heterogeneous catalyst. Heterogeneous catalyst is environmentally friendly, easy to separate, recycle and cheaper to produce biodiesel for running compression ignition diesel engine. The result of this work would serve as baseline data for biodiesel production from non-edible sand apple oil. This study, therefore, evaluated the performance of a compression ignition engine (CIE) fuelled with biodiesel produced from sand apple (Parinari polyandra B.) oil using eggshell as catalyst keeping in mind the properties that could affect the performance of the engine.

\section{MATERIALS AND METHODS}

\subsection{Experimental Set-up}

A single cylinder, $3.68 \mathrm{~kW}$ diesel engine made by Kipor Machinery Company was used for the performance evaluation. The test was carried out in the Automation Laboratory of Mechanical Engineering Department, Ladoke Akintola University of Technology, Ogbomoso, Nigeria. The engine was coupled to a Hydraulic Dynamometer made by $\mathrm{AL}-$ Tech BK. A water tank was placed above the level of the dynamometer for cooling. The water was passed into the dynamometer through an air vent and discharged into the drain tank. Attached to the drain tank was a water pump that pumped the drained water back to the tank to maintain constant water supply to the dynamometer.

The $3.68 \mathrm{~kW}$ engine shaft drove the paddle in the valve casing, churning up the water in the dynamometer. This casing was restricted from rotating at the same speed with the paddle by a spring loaded nylon cord that passes round the casing. The tension of the two springs was always equal as the dynamometer casing rotates. A damper, which was connected to the casing, was filled with thick oil. The angular position taken up by the casing depends on the torque and stiffness of the two springs. Angular displacement of the casing was proportional to the torque which was measured by the calibration of the arm of the dynamometer by a rotary potentiometer that fed the output into the input of TDII4 torque meter.

\subsection{Testing Procedure}

The diesel fuel used in the experiment was obtained from the NNPC Filling Station, Ogbomoso, Nigeria. The specifications of the $3.68 \mathrm{~kW}$ engine (Fig. 1) is presented in Table 1 . The engine was
Table 1: Specification of the $3.68 \mathrm{~kW}$ diesels engine .

\begin{tabular}{lll}
\hline S/N & Engine parameter & Engine Specification \\
\hline 1 & Maker & Kipor Machinery Company \\
2 & Model & KM 178 F (A) \\
3 & Type & Air Cooled diesel Engine \\
4 & Rated power & $3.6 \mathrm{~kW}(3.3 \mathrm{hp})$ \\
5 & Rated speed & $3000 \mathrm{rpm}$ \\
6 & Maximum power & $3.68 \mathrm{~kW}(5 \mathrm{hp})$ \\
7 & Number of cylinders & 1 \\
8 & Valve clearance & $-0.10-0.15$ \\
9 & Cooling system & Air cooled \\
10 & Lubricating No & SAE 10W -30 \\
11 & Net weight & $40 \mathrm{~kg}$ \\
12 & Fuel capacity & $3.5 \mathrm{litres}$ \\
\hline
\end{tabular}

Source: TQTD110-TD115 small engine manual for test bed and instrumentation

first operated with AGO blend fuel. It was operated with Wide Open Throttle (WOT) on no load condition for $5 \mathrm{~min}$. The engine was allowed to run for 2 min at half throttle and then increased gradually until it reached WOT for each of the fuel blends tested. The engine was operated at no load, $25 \%, 50 \%, 75 \%$ and $100 \%$ loading conditions at 2 min intervals when the engine was loaded with SAEE-AGEO blends of B5, B10, B15, B20 and B25 as recommended by $[12,13]$.

In a similar manner, the engine was loaded using sand apple ethyl ester blended with AGO having as recommended by $[12,13]$. This method was used to obtain values for torques, speed, fuel consumption rate and exhaust temperature at no load, 25, 50, 75 and $100 \%$ loading as recommended by [13].

To determine the stable torque range of the engine, a preliminary test was carried out. Water flowing into the dynamometer was allowed for 2 min during which the inlet valve control knob was used to regulate the inflow of water into dynamometer until a stable, desired torque was attained.

\subsubsection{Determination of fuel consumption rate}

The engine fuel consumption rate was determined using parameters in Eq. (1) [13].

$$
M_{f}=\frac{8 \rho \times 10^{-4}}{t}, \mathrm{~kg} / \mathrm{s}
$$

where $M_{f}$ is fuel consumption rate $(\mathrm{kg} / \mathrm{s}), \rho$ is density of fuel $\left(\mathrm{kg} / \mathrm{m}^{3}\right)$ and $t=$ Time taken $(\mathrm{s})$

\subsubsection{Determination of fuel equivalent power}

The fuel equivalent power was determined using Eq. (2) [13]

$$
P_{f}=H_{g} \times M_{f}
$$

where $P_{f}$ is fuel equivalent power (W), $M_{f}$ is fuel consumption rate $(\mathrm{kg} / \mathrm{h})$ and $H_{g}$ is heating value $(\mathrm{J} / \mathrm{kg})$. 


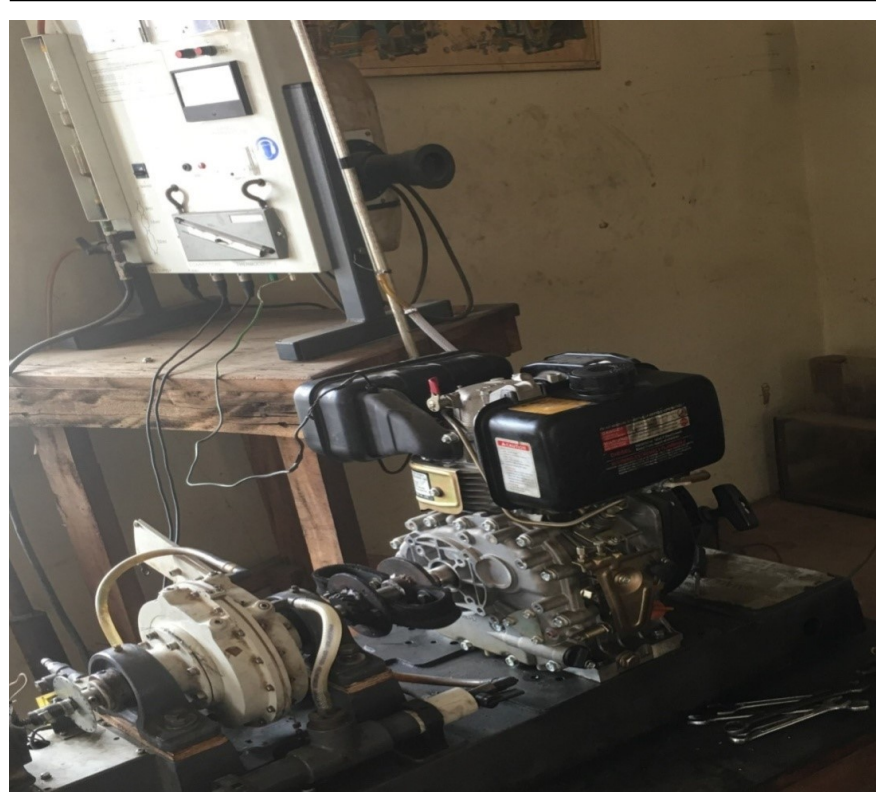

Figure 1: Experimental set-up for engine performance test.

\subsubsection{Determination of brake power}

The brake power $P_{B}$ output was determined using Eqs. (3) and (4) [13].

$$
P_{B}=\frac{2 \pi N T}{60}
$$

where $N$ is speed (rpm) and $T$ is torque (Nm)

$$
\omega=\frac{2 \pi N}{60}
$$

Therefore,

$$
P_{B}=T \omega
$$

where $\omega$ is angular speed $(\mathrm{rad} / \mathrm{s})$.

\subsubsection{Determination of brake specific fuel con- sumption (BSFC)}

The brake specific fuel consumption measures the efficiency of an engine to produce useful work. The BSFC can be calculated using Eq. (6) [13, 14]

$$
B S F C=\frac{M_{f}}{P_{B}}
$$

where $B S F C$ is brake specific fuel consumption $(\mathrm{kg} / \mathrm{kWh}), M_{f}$ is fuel consumption rate $(\mathrm{kg} / \mathrm{s})$ and $P_{B}$ is brake power $(\mathrm{kW})$.

\subsubsection{Determination of brake thermal efficiency (BTE)} [13].

The BTE $\left(\eta_{B t h}\right)$ was determined using Eq. (6)

$$
\eta_{B t h}=\frac{P_{B}}{c_{f} \times H_{g}} \times 100
$$

where $\eta_{B t h}$ is brake thermal efficiency $(\%), P_{B}$ is brake power $(\mathrm{kW}), f$ is fuel consumption rate $(\mathrm{kg} / \mathrm{h})$ and $H_{g}$ is heating value $(\mathrm{J} / \mathrm{kg})$.

\section{RESULTS AND DISCUSSION}

Figure 2 (Tables A.3) presents the results of the engine performance tests using $100 \%$ AGO while, Figs. $3-7$ (Tables A.3 - A.8) presents the engine performance tests results of using SAEEAGO blends of B5, B10, B15, B20 and B25. The results of the Analysis of Variance (ANOVA) of the engine performance of SAEE-AGO blends using Duncan Multiple Range Test (DMRT) is shown in Table 2. The engine performance criteria presented in the tables are; engine torque, engine speed, engine fuel consumption rate, engine exhaust temperature, fuel equivalent power, brake specific fuel consumption, brake power and brake thermal efficiency at different loading rates.

\subsection{Engine Torque}

Figure 2 (Tables A.3 shows the performance test obtained for $3.68 \mathrm{~kW}$ compression ignition engine using AGO. It was observed that at no loading condition, a torque of $7.2 \mathrm{Nm}$ was developed and it kept increasing to a peak value of $10.10 \mathrm{Nm}$ at $100 \%$ full loading condition. The engine torque for SAEE-AGO blends (B5, B10, B15, B20 and B25) are shown in Figs. 3 - 7 (Tables A.4 - A.8) respectively. Torque developed increased with increase in loading conditions and ranged from 6.6 to $8.5,6.0$ to $7.9,5.70$ to $7.50,5.10$ to 7.2 and 4.75 to $6.5 \mathrm{Nm}$, respectively. At $100 \%$ loading condition, the peak value for B5 to B25 were 8.5, 7.90, $7.5,7.2$ and $6.5 \mathrm{Nm}$ respectively. The bottom line is that as the blend increases, engine torque developed decreases. This trend is similar to the findings of [13] who reported that $8.47 \mathrm{Nm}$ peak value was recorded for Loofah-AGO blends at all loading conditions. The DMRT in Table 2 showed that SAEE-AGO blends have significant effect on engine torque at $5 \%$ level of significance.

\subsection{Engine Speed}

The speed of the AGO-fired engine decreased with increase in engine loading condition (Fig. 2; Tables A.3) and the engine developed the highest speed of $3000 \mathrm{rpm}$ at no load condition and lowest speed value of $2990 \mathrm{rpm}$ at $100 \%$ full load condition. Similarly, at B5 to B25 in Fig. 3 - 7 (Tables A.4 - A.8), the engine speed decreased with increased in blends from the peak value of 2950 to $2795 \mathrm{rpm}$ at $100 \%$ loading conditions. The DMRT (Table 2) revealed that SAEE - AGO blends engine speed has no significant effect $(\mathrm{P}<0.05)$ on engine speed. This shows that the sand apple biodiesel can be used as an alternative in a compression ignition engine.

\subsection{Engine Exhausts Gas Temperature}

The exhaust gas temperature from the $3.68 \mathrm{~kW}$ diesel engine at various loading conditions for AGO is presented in Fig. 2 (Tables A.3). The exhaust gas temperature increased with increase in the blends. Results obtained shows that it increased from 405 to $815^{\circ} \mathrm{C}$ from no load to $100 \%$ full load in AGO. The values of exhaust gas temperature for SAEE - AGO blends obtained are 


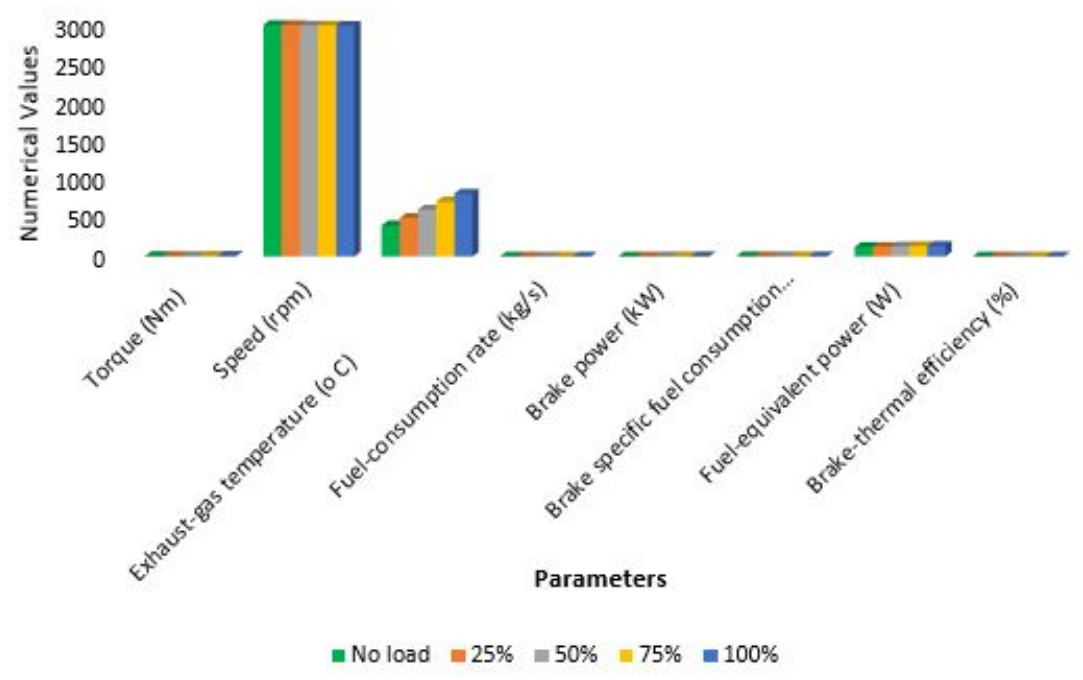

Figure 2: Performance test on $3.68 \mathrm{~kW}$ diesel engines using AGO blend.

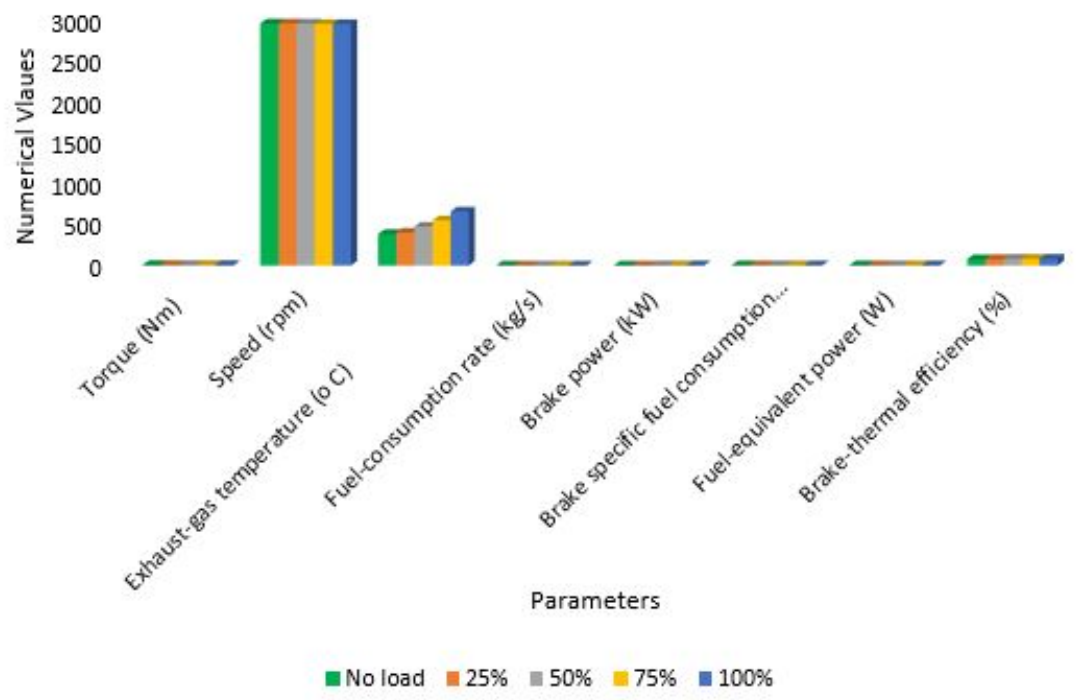

Figure 3: Performance test on $3.68 \mathrm{~kW}$ diesel engines using B5 blend.

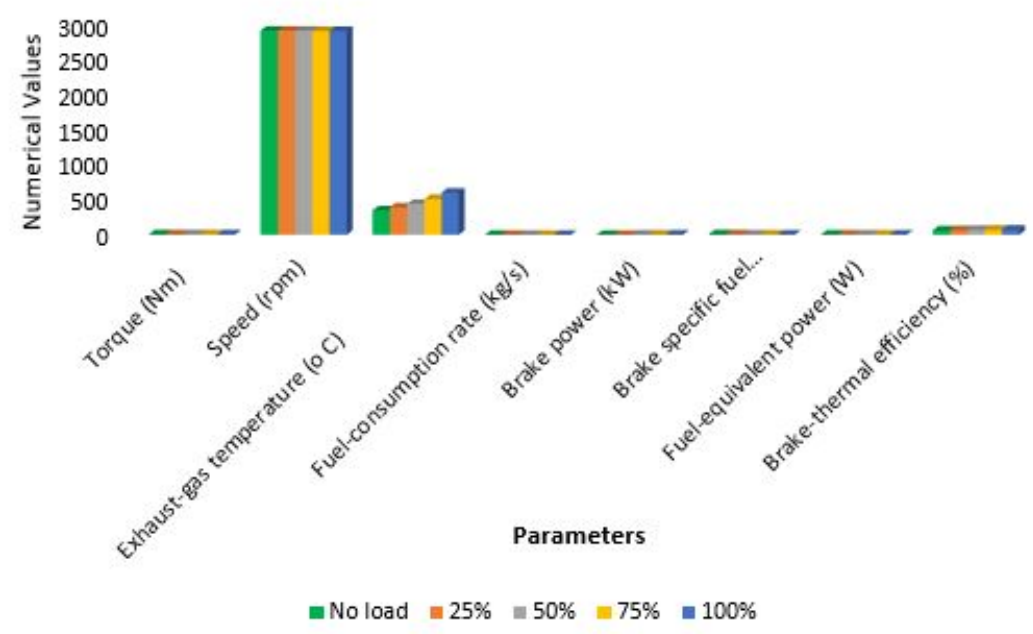

Figure 4: Performance test on $3.68 \mathrm{~kW}$ diesel engines using B10 blend. 


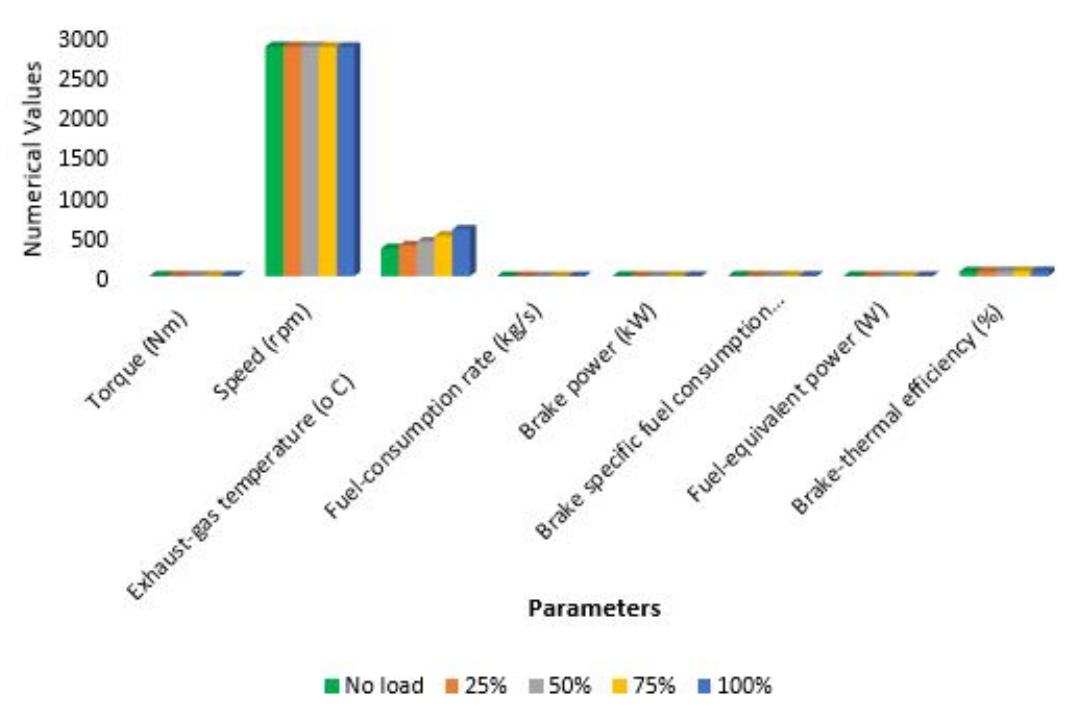

Figure 5: Performance test on $3.68 \mathrm{~kW}$ diesel engines using B15 blend.

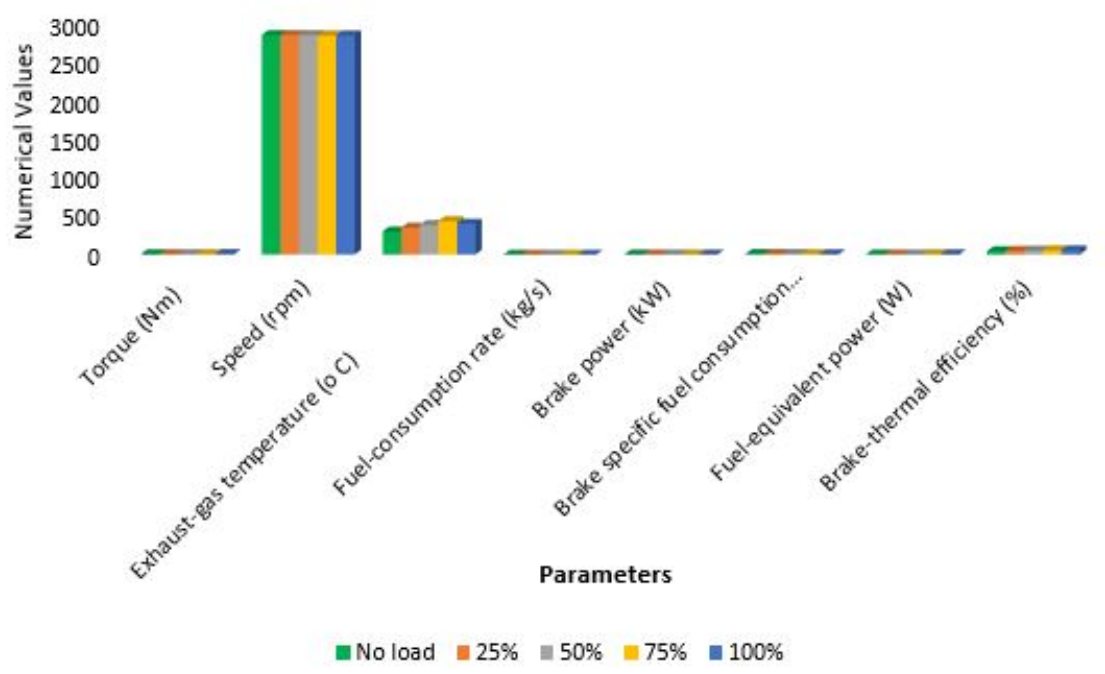

Figure 6: Performance test on $3.68 \mathrm{~kW}$ diesel engines using B20 blend.

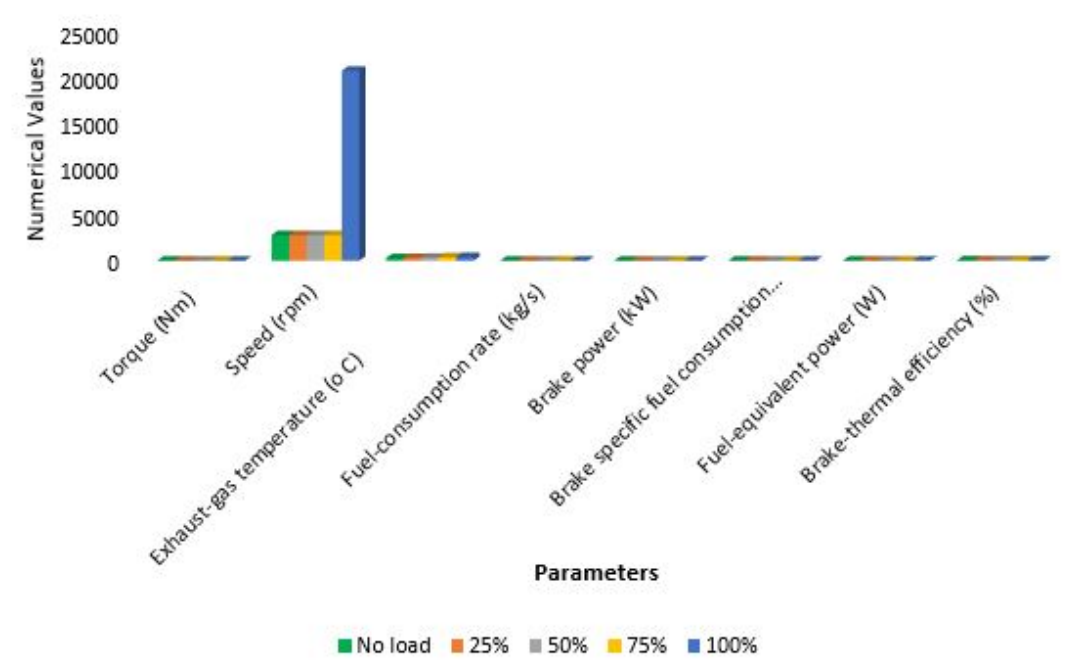

Figure 7: Performance test on $3.68 \mathrm{~kW}$ diesel engines using B25 blend. 
Table 2: ANOVA of engine performance of sand apple ethyl ester - AGO blends.

\begin{tabular}{|c|c|c|c|c|c|c|c|}
\hline Parameters & Units & & Sum of Squares & Df & Mean Square & $\mathbf{F}$ & Sig. \\
\hline \multirow{3}{*}{ Torque } & \multirow{3}{*}{$\mathrm{Nm}$} & Treatments & 16.552 & 4 & 4.138 & 26.951 & .000 \\
\hline & & Error & 1.535 & 10 & .154 & & \\
\hline & & Total & 18.087 & 14 & & & \\
\hline \multirow{3}{*}{ Speed } & \multirow{3}{*}{ rpm } & Treatments & 210.000 & 4 & 52.500 & 2.625 & .098 \\
\hline & & Error & 200.000 & 10 & 20.000 & & \\
\hline & & Total & 410.000 & 14 & & & \\
\hline Exhaust Gas & \multirow{3}{*}{${ }^{\circ} \mathrm{C}$} & Treatments & 319598.400 & 4 & 79899.600 & 2874.086 & .000 \\
\hline \multirow[t]{2}{*}{ Temperature } & & Error & 278.000 & 10 & 27.800 & & \\
\hline & & Total & 319876.400 & 14 & & & \\
\hline Fuel consumption & \multirow{3}{*}{$\mathrm{kg} / \mathrm{s}$} & Treatments & .000 & 4 & .000 & .267 & .892 \\
\hline \multirow{2}{*}{ Rate } & & Error & .000 & 10 & .000 & & \\
\hline & & Total & .000 & 14 & & & \\
\hline \multirow{3}{*}{ Brake power } & \multirow{3}{*}{$\mathrm{kW}$} & Treatments & 1.590 & 4 & .398 & 42.660 & .000 \\
\hline & & Error & .093 & 10 & .009 & & \\
\hline & & Total & 1.684 & 14 & & & \\
\hline Brake Specific fuel & \multirow{3}{*}{$\mathrm{g} / \mathrm{kWh}$} & Treatments & 1.617 & 4 & .404 & 518.154 & .000 \\
\hline \multirow[t]{2}{*}{ Consumption } & & Error & .008 & 10 & .001 & & \\
\hline & & Total & $1.624^{a}$ & 14 & & & \\
\hline \multirow{3}{*}{$\begin{array}{l}\text { Fuel Equivalent } \\
\text { power }\end{array}$} & \multirow{3}{*}{ W } & Treatments & 414.915 & 4 & 103.729 & 220.343 & .000 \\
\hline & & Error & 4.708 & 10 & .471 & & \\
\hline & & Total & 419.623 & 14 & & & \\
\hline Brake Thermal & \multirow{3}{*}{$\%$} & Treatments & .436 & 4 & .109 & 139.885 & .000 \\
\hline \multirow[t]{2}{*}{ Efficiency } & & Error & .008 & 10 & .001 & & \\
\hline & & Total & .444 & 14 & & & \\
\hline
\end{tabular}

given in Fig. 3 - 7 (Tables A.4 - A.8). These results revealed that as the load increases, the exhaust gas temperature also increases and ranged from 401 to $660^{\circ} \mathrm{C}, 350$ to $600^{\circ} \mathrm{C}, 380$ to $580^{\circ} \mathrm{C}, 350$ to $400^{\circ} \mathrm{C}$ and 300 to $400^{\circ} \mathrm{C}$ for B5, B10, B15, B20 and B25, respectively. When comparing SAEE- AGO blends to AGO, it was observed that the exhaust gas temperatures increase as the blend increases. The DMRT in Table 2 revealed that SAEE - AGO blends has significant effect $(\mathrm{P}<0.05)$ on engine exhaust gas temperature.

\subsection{Fuel Consumption Rate}

Fuel consumption rate at different loading conditions when the engine was fired by AGO is presented in Fig. 2 (Tables A.3). The result depicted that the fuel consumption rate increased as the loading rate increases. The maximum fuel consumption rate of $3.15 \times 10^{-6} \mathrm{~kg} / \mathrm{s}$ was obtained at full loading (100\%) condition. The consumption rate for B5 to B25 increased from $2.95 \times 10^{-6}$ to $5.0 \times 10^{-6} \mathrm{~kg} / \mathrm{s}$ when the loading condition increases. The increase in fuel consumption rate at all loading conditions could be as a result of increase in mechanical and pumping losses. This is similar to the report of [15] who observed that the fuel consumption of a diesel engine fuelled with waste cooking oil biodiesel blends increased as the loading condition increases. The DMRT showed in Table 2 revealed that SAEE - AGO blends has significant effect on the rate of engine fuel consumption at $5 \%$ level of significance.

\subsection{Engine Brake Specific Fuel Consump- tion}

The result of the engine break specific fuel consumption (BSFC) rate at different loading con- ditions is presented in Fig. 2 (Tables A.3) for AGO. The BSFC on the $3.68 \mathrm{~kW}$ diesel engines decreased from 4.50 to $3.59 \mathrm{~g} / \mathrm{kWh}$ when the loading condition increases. Similar trend was observed on engine BSFC when SAEE - AGO blends was used. The decrease in BSFC is observed in Fig. 3 - 7 (Tables A.4 - A.8) for B5, B10, B15, B20 and B25, respectively which ranged from 5.16 to 4.73 , 6.12 to $5.38,6.97$ to $6.34,8.68$ to 6.98 and 11.46 to $9.47 \mathrm{~g} / \mathrm{kWh}$, respectively. As the blends increase the brake specific fuel consumption rate decreases at all loading conditions. Research findings from [16] showed that diesel had a lower specific fuel consumption rate compared to castor oil - AGO blends. The DMRT in Table A.8 revealed that SAEE - AGO blends has significant effect $(\mathrm{P}<$ $0.05)$ on engine BSFC.

\subsection{Engine Brake Power}

The engine brake power with AGO as the reference fuel is presented in Fig. 2 (Tables A.3). The engine brake power increased from 2.26 to 3.16 $\mathrm{kW}$ when the loading condition increases from no load to $100 \%$ full loading condition when used on $3.68 \mathrm{~kW}$ diesel engines. The same trend was observed using SAEE - AGO blends from no load to $100 \%$ full load. At B5, B10, B15, B20 and B25, the engine brake power increases and ranged from 2.04 to $2.62,1.82$ to $2.40,1.70$ to $2.23,1.52$ to 2.15 and 1.39 to $1.90 \mathrm{~kW}$, respectively. The results revealed that as the blends increased from B5 to B25, the engine brake power decreased from 2.62 to $1.90 \mathrm{~kW}$ at $100 \%$ loading condition. The DMRT in Table 2 revealed that SAEE - AGO blends has significant effect on brake power at $5 \%$ significance. 


\subsection{Engine Fuel Equivalent Power of Fuel Sample}

The results of the engine fuel equivalent power using AGO are also presented in Fig. 2 (Tables A.3), as the load increases, the engine fuel equivalent power also increased. The engine fuel equivalent power increased using SAEE - AGO blends as the loading condition increases. At B5, B10, B15, B20 and B25 blends in Fig. 3 - 7 (Tables A.4 A.8), the engine fuel equivalent power increased and ranged from 2.65 to $3.12,2.85$ to $3.26,2.99$ to $3.57,3.33$ to 3.79 and 3.99 to $4.51 \mathrm{~W}$, respectively. The same trend was followed when compared with AGO, as the blends increase from B5 to B25, the engine fuel equivalent power increases at all loading conditions. This agrees with [13] on performance characteristics of loofah biodiesel AGO blends in $2.46 \mathrm{~kW}$ diesel engines that the maximum fuel equivalent power increased from $4576 \mathrm{~W}$ to $628 \mathrm{~W}$ at different loading conditions. The DMRT in Table 2 revealed that SAEE - AGO blends has significant effect $(\mathrm{P}<0.05)$ on engine fuel equivalent power of fuel sample.

\subsection{Engine Brake Thermal Efficiency}

The engine brake thermal efficiency (EBTE) results for AGO are presented in Fig. 2 (Tables A.3). It was observed that the EBTE increased when the loading conditions increases. The EBTE increased at no load from1.79 to $2.26 \%$ at full load. Results obtained were presented in Fig. 3- 7 (Tables A.4 - A.8), the EBTE increased in a similar way to AGO, when the loading conditions increases from no load to $100 \%$ load. The results revealed that the EBTE decreased with increase in the proportion of the SAEE in the blend. At $\mathrm{B} 5, \mathrm{~B} 10, \mathrm{~B} 15, \mathrm{~B} 20$ and B25 the EBTE decreased and ranged from 76.98 to $83.97,64.54$ to 73.62 , 56.86 to $62.46,45.64$ to 56.73 and 34.84 to $42.13 \%$, respectively. Among the blends, B5 was found to have the maximum EBTE of $83.97 \%$. The DMRT in Table 2 revealed that SAEE - AGO blends has significant effect on engine brake thermal efficiency at $5 \%$ level of significance.

\section{CONCLUSION}

The performance of a Compression Ignition Engine fuelled with Sand Apple Ethyl Ester, SAEE (biodiesel) produced using eggshell (a heterogeneous catalyst) has been evaluated and found suitable for use in the engine. The engine torque, speed, brake power, brake specific fuel consumption, fuel consumption rate, engine exhaust temperature, fuel equivalent power and the brake thermal efficiency of the various blends of SAEEAGO in the engine performance has no significant difference compared with using 100\% AGO. Engine loading significantly affect the engine performance when fuelled with the SAEE-AGO blends and there is no significant difference between the performances of the CIE when fuelled with AGO and SAEE-AGO blends at all loading considered.

\section{References}

[1] G. Huang, F. Chen, D. Wei, X. Zhang, and G. Chen, "Biodiesel production by microalgae biotechnology," Journal of Applied Energy, vol. 87, no. 1, pp. 38-46, 2010.

[2] "Standard specification for biodiesel fuel blend stock for middle distilled fuels," American Society for Testing and Material (ASTM D6751), pp. 3421-3442, 2018.

[3] EN 14214, "Standard specification for biodiesel fuel blend stock for middle distilled fuels," European committee for standardization describe the requirement and test method for fatty acid methyl ester, 2018.

[4] A. A. Demirbas, "Potential resources of non-edible oils for biodiesel," Journal of Energy Source Part B, vol. 4, pp. 310-314, 2009.

[5] A. Demirbas, "Biodiesel from vegetable oils with $\mathrm{MgO}$ catalytic transesterification in Supercritical methanol," Journal of Energy Source Part A, vol. 30, no. Part A, pp. 1645-1651, 2008.

[6] M. Demirbas and M. Balat, "Recent advances on the production and utilization trends of bio-fuels: a global perspective," Journal of Energy Convers Manage, vol. 47 , no. 15 , pp. $2371-2381,2006$.

[7] M. Balat and H. Balat, "A critical review of biodiesel as a vehicular fuel," Journal of Energy Convers Manage, vol. 86 , no. 11 , pp. 2273-2282, 2008.

[8] A. Chhetri, K. Watts, and M. Islam, "Waste cooking oil as an alternate feedstock for biodiesel production," Energies journal, vol. 1 , no. 1, pp. 3-18, 2008.

[9] A. Bamgboye and A. Hansen, "Prediction of cetane number of biodiesel fuel from the Fatty acid methyl ester (FAME) composition," International journal of Agrophysis, vol. 22, no. 1, pp. 21-29, 2008.

[10] M. Balat, "Modeling vegetable oil viscosity," Journal of Energy Source, vol. 30, pp. 1856-1869, 2008.

[11] B. Kulkarni, B. Pujar, and S. Shanmukhappa, "Investigation of acid oil as a source of biodiesel," Indian Journal of Chemical Technology, vol. 15, no. 1, pp. 467-471, 2008.

[12] D. Shrestha, J. Gerpen, I. Thompson, and A. Zanadziki, "A cold flow properties of biodiesel fuel," Report of ASAE Annual International meeting, 2005.

[13] O. Oniya and A. Bamgboye, "Production of biodiesel from groundnut (Arachis hypogea, L.) oil," Agricultural Engineering International CIGR Journal, vol. 16, no. 143, pp. 143-150, 2014.

[14] J. Nwakaire, O. Obi, C. Ohagwu, C. Anyadike, I. Ugwu, and J. Ifoh, "Fuel efficiency and exhaust characteristics of turbocharged diesel engine equipped with an electric supercharger," Nigerian Journal of Technology, vol. 39, no. 3, pp. 761-766, 2020.

[15] Wail and Khaled, "Performance of diesel engine fuelled by a biodiesel exracted from a waste cooking oil," Energy Procedia, vol. 18, pp. 1317-1334, 2012.

[16] C. Prasad, I. Reddy, I. Kumar, I. Ramjee, O. Hebbel, and M. Nivendgi, "Performance and emission characteristics of a diesel engine with castor oil," Indian journal of Science and Technology, vol. 2, pp. 24-31, 2009.

Appendix A. Tables

Appendix A.1. Performance Test on $3.68 \mathrm{~kW}$ Diesel Engines for Various Blends 
Table A.3: Performance test on $3.68 \mathrm{~kW}$ diesel engines using AGO blend.

\begin{tabular}{|c|c|c|c|c|c|}
\hline \multirow{2}{*}{ Parameter } & \multicolumn{5}{|c|}{ Load } \\
\hline & No load & $\mathbf{2 5 \%}$ & $50 \%$ & $75 \%$ & $100 \%$ \\
\hline Torque $(\mathrm{Nm})$ & 7.20 & 7.85 & 8.65 & 9.47 & 10.10 \\
\hline Speed (rpm) & 3000 & 3000 & 2995 & 2995 & 2990 \\
\hline Exhaust-gas & 405 & 501 & 610 & 713 & 815 \\
\hline $\begin{array}{l}\text { temperature }\left(^{\circ}\right) \\
\text { Fuel-consumption } \\
\text { rate }(\mathrm{kg} / \mathrm{s})\end{array}$ & $2.825 \times 10^{-6}$ & $2.875 \times 10^{-6}$ & $2.992 \times 10^{-6}$ & $3.058 \times 10^{-6}$ & $3.15 \times 10^{-6}$ \\
\hline Brake power $(\mathrm{kW})$ & 2.26 & 2.47 & 2.71 & 2.97 & 3.16 \\
\hline $\begin{array}{l}\text { Brake specific } \\
\text { fuel consumption ( } \mathrm{g} / \mathrm{kwh})\end{array}$ & 4.50 & 4.19 & 3.97 & 3.71 & 3.59 \\
\hline Fuel-equivalent power (W) & 125.46 & 127.68 & 132.87 & 135.80 & 139.89 \\
\hline Brake-thermal efficiency $(\%)$ & 1.79 & 1.93 & 2.04 & 2.19 & 2.26 \\
\hline
\end{tabular}

Table A.4: Performance test on $3.68 \mathrm{~kW}$ diesel engines using B5 blend.

\begin{tabular}{lccccc}
\hline \multirow{2}{*}{ Parameter } & \multicolumn{5}{c}{ Load } \\
\cline { 2 - 6 } & No load & $\mathbf{2 5 \%}$ & $50 \%$ & $75 \%$ & $100 \%$ \\
\hline Torque (Nm) & 6.60 & 6.95 & 7.60 & 8.10 & 8.50 \\
Speed (rpm) & 2950 & 2950 & 2950 & 2945 & 2945 \\
Exhaust-gas & 385 & 401 & 475 & 550 & 660 \\
temperature ( $\left.{ }^{\circ}\right)$ & & & & \\
Fuel-consumption & $2.925 \times 10^{-6}$ & $2.998 \times 10^{-6}$ & $3.108 \times 10^{-6}$ & $3.258 \times 10^{-6}$ & $3.442 \times 10^{-6}$ \\
rate (kg/s) & 2.04 & 2.15 & 2.35 & 2.50 & 2.62 \\
$\begin{array}{l}\text { Brake power (kW) } \\
\text { Brake specific }\end{array}$ & 5.16 & 5.02 & 4.76 & 4.69 & 4.73 \\
fuel consumption (g/kwh) & 2.65 & 2.72 & 2.82 & 2.95 & 3.12 \\
Fuel-equivalent power (W) & 76.98 & 79.04 & 83.33 & 84.74 & 83.97 \\
Brake-thermal efficiency (\%) & & & & & \\
\hline
\end{tabular}

Table A.5: Performance test on $3.68 \mathrm{~kW}$ diesel engines using B10 blend.

\begin{tabular}{|c|c|c|c|c|c|}
\hline \multirow{2}{*}{ Parameter } & \multicolumn{5}{|c|}{ Load } \\
\hline & No load & $25 \%$ & $50 \%$ & $75 \%$ & $100 \%$ \\
\hline Torque $(\mathrm{Nm})$ & 6.00 & 6.40 & 7.00 & 7.45 & 7.90 \\
\hline Speed (rpm) & 2900 & 2900 & 2900 & 2895 & 2895 \\
\hline Exhaust-gas & 350 & 390 & 440 & 510 & 600 \\
\hline temperature $\left(^{\circ}\right)$ & & & & & \\
\hline $\begin{array}{l}\text { Fuel-consumption } \\
\text { rate }(\mathrm{kg} / \mathrm{s})\end{array}$ & $3.092 \times 10^{-6}$ & $3.158 \times 10^{-6}$ & $3.258 \times 10^{-6}$ & $3.425 \times 10^{-6}$ & $3.583 \times 10^{-6}$ \\
\hline Brake power $(\mathrm{kW})$ & 1.82 & 1.94 & 2.13 & 2.26 & 2.4 \\
\hline $\begin{array}{l}\text { Brake specific } \\
\text { fuel consumption ( } \mathrm{g} / \mathrm{kwh})\end{array}$ & 6.12 & 5.86 & 5.51 & 5.46 & 5.38 \\
\hline Fuel-equivalent power (W) & 2.82 & 2.88 & 2.97 & 3.12 & 3.26 \\
\hline Brake-thermal efficiency (\%) & 64.54 & 67.36 & 71.72 & 72.43 & 73.62 \\
\hline
\end{tabular}


Table A.6: Performance test on $3.68 \mathrm{~kW}$ diesel engines using B15 blend.

\begin{tabular}{|c|c|c|c|c|c|}
\hline \multirow{2}{*}{ Parameter } & \multicolumn{5}{|c|}{ Load } \\
\hline & No load & $25 \%$ & $50 \%$ & $75 \%$ & $100 \%$ \\
\hline Torque $(\mathrm{Nm})$ & 5.70 & 6.20 & 6.90 & 7.15 & 7.50 \\
\hline Speed (rpm) & 2850 & 2850 & 2850 & 2845 & 2845 \\
\hline $\begin{array}{l}\text { Exhaust-gas } \\
\text { temperature }\left(^{\circ}\right)\end{array}$ & 345 & 380 & 430 & 500 & 580 \\
\hline $\begin{array}{l}\text { Fuel-consumption } \\
\text { rate }(\mathrm{kg} / \mathrm{s})\end{array}$ & $3.292 \times 10^{-6}$ & $3.425 \times 10^{-6}$ & $3.658 \times 10^{-6}$ & $3.758 \times 10^{-6}$ & $3.925 \times 10^{-6}$ \\
\hline Brake power $(\mathrm{kW})$ & 1.70 & 1.85 & 2.06 & 2.13 & 2.23 \\
\hline $\begin{array}{l}\text { Brake specific } \\
\text { fuel consumption ( } \mathrm{g} / \mathrm{kwh})\end{array}$ & 6.97 & 6.66 & 6.39 & 6.35 & 6.34 \\
\hline Fuel-equivalent power (W) & 2.99 & 3.11 & 3.32 & 3.42 & 3.57 \\
\hline Brake-thermal efficiency (\%) & 56.86 & 59.48 & 62.05 & 62.28 & 62.46 \\
\hline
\end{tabular}

Table A.7: Performance test on $3.68 \mathrm{~kW}$ diesel engines using B20 blend.

\begin{tabular}{|c|c|c|c|c|c|}
\hline \multirow{2}{*}{ Parameter } & \multicolumn{5}{|c|}{ Load } \\
\hline & No load & $25 \%$ & $50 \%$ & $75 \%$ & $100 \%$ \\
\hline Torque $(\mathrm{Nm})$ & 5.10 & 5.80 & 6.40 & 6.95 & 7.20 \\
\hline Speed (rpm) & 2850 & 2850 & 2850 & 2845 & 2845 \\
\hline Exhaust-gas & 300 & 350 & 385 & 435 & 400 \\
\hline temperature $\left(^{\circ}\right)$ & & & & & \\
\hline $\begin{array}{l}\text { Fuel-consumption } \\
\text { rate }(\mathrm{kg} / \mathrm{s})\end{array}$ & $3.667 \times 10^{-6}$ & $3.767 \times 10^{-6}$ & $3.925 \times 10^{-6}$ & $4.0 \times 10^{-6}$ & $4.167 \times 10^{-6}$ \\
\hline Brake power $(\mathrm{kW})$ & 1.52 & 1.73 & 1.91 & 2.07 & 2.15 \\
\hline $\begin{array}{l}\text { Brake specific } \\
\text { fuel consumption ( } \mathrm{g} / \mathrm{kwh})\end{array}$ & 8.68 & 7.84 & 7.40 & 6.96 & 6.98 \\
\hline Fuel-equivalent power (W) & 3.33 & 3.43 & 3.57 & 3.64 & 3.79 \\
\hline Brake-thermal efficiency $(\%)$ & 45.64 & 50.44 & 53.50 & 56.87 & 56.73 \\
\hline
\end{tabular}

Table A.8: Performance test on $3.68 \mathrm{~kW}$ diesel engines using B25 blend.

\begin{tabular}{|c|c|c|c|c|c|}
\hline \multirow[b]{2}{*}{ Parameter } & \multicolumn{5}{|c|}{ Load } \\
\hline & No load & $25 \%$ & $50 \%$ & $75 \%$ & $100 \%$ \\
\hline Torque $(\mathrm{Nm})$ & 4.75 & 5.00 & 5.50 & 6.10 & 6.50 \\
\hline Speed (rpm) & 2800 & 2800 & 2800 & 2800 & 20795 \\
\hline Exhaust-gas & 270 & 300 & 340 & 375 & 400 \\
\hline temperature $\left(^{\circ}\right)$ & & & & & \\
\hline $\begin{array}{l}\text { Fuel-consumption } \\
\text { rate }(\mathrm{kg} / \mathrm{s})\end{array}$ & $4.425 \times 10^{-6}$ & $4.5 \times 10^{-6}$ & $4.6 \times 10^{-6}$ & $4.767 \times 10^{-6}$ & $5.0 \times 10^{-6}$ \\
\hline Brake power $(\mathrm{kW})$ & 1.39 & 1.47 & 1.61 & 1.79 & 1.90 \\
\hline $\begin{array}{l}\text { Brake specific } \\
\text { fuel consumption ( } \mathrm{g} / \mathrm{kwh})\end{array}$ & 11.46 & 11.02 & 10.29 & 9.59 & 9.47 \\
\hline Fuel-equivalent power (W) & 3.99 & 4.06 & 4.15 & 4.30 & 4.51 \\
\hline Brake-thermal efficiency (\%) & 34.84 & 36.21 & 38.79 & 41.63 & 42.13 \\
\hline
\end{tabular}

